๑ Entomologica Fennica. 19 September 2003

\title{
Distribution and nymphal age of Dinocras cephalotes (Curtis) (Plecoptera: Perlidae) in northern Finland
}

\author{
Heikki Erkinaro \& Jaakko Erkinaro
}

Erkinaro, H. \& Erkinaro, J. 2003: Distribution and nymphal age of Dinocras cephalotes (Curtis) (Plecoptera: Perlidae) in northern Finland. - Entomol. Fennica 14: 125-128.

The largest species of Scandinavian plecopterans, Dinocras cephalotes (Curtis), was identified in the River Inarijoki, northern Finnish Lapland in 1990, being the first record of this species in Finland. In spite of the widespread zoobenthos survey carried out in all major river systems in the northernmost Lapland, the distribution of $D$. cephalotes seems to be restricted to a small geographical area in the R. Inarijoki, which forms part of the border between northern Norway and Finland. The nymphal stage of $D$. cephalotes appears to take four years in northern Finland, and no indications of a five-year nymphal stage, earlier suggested for northernmost Scandinavia, were found.

Heikki Erkinaro \& Jaakko Erkinaro, River Tenojoki Fisheries Research Station, Finnish Game and Fisheries Research Institute, FIN-99980 Utsjoki, Finland

Jaakko Erkinaro, Oulu Game and Fisheries Research, Finnish Game and Fisheries Research Institute, Tutkijantie 2, FIN-90570 Oulu, Finland; Email:jaakko.erkinaro@rktl.fi

Received 13 March 2002, accepted 26 May 2003

\section{Introduction}

Dinocras cephalotes (Curtis) is the largest stonefly species in Scandinavia, reaching a maximum body length of $30 \mathrm{~mm}$. Its distribution in northern Scandinavia is restricted to certain river systems in Finnmark, northern Norway (Lillehammer 1974, Huru 1987) and northern Sweden (Mendl \& Müller 1974), and no records have previously been available from northern Finland (Meinander 1980).

Given the large size, predaceous behaviour and multi-year life cycle of $D$. cephalotes, the species' life history (Frutiger 1987, Huru 1987), behaviour (Sjöström 1985) and feeding (Malmqvist \& Sjöström 1980, Lucy et al. 1990) have been widely studied. In southern Scandinavia the eggs are laid in spring and the nymphs emerge later in the same summer (Brinck 1949). In contrast, in the northern part of the distribution area the eggs may stay in parapause (sensu Zwick 1996a) over the following winter and emerging takes place in the second summer (Ulfstrand 1968, Lillehammer 1987). A three-year development period of the nymphs (nymphal ages $0+, 1+$ and 2+; cf. Lucy et al. [1990]) has been shown for most of the species' distribution area (Brinck 1949, Hynes 1977) but the nymph development may take longer towards the north (Ulfstrand 1968, Huru 1987).

In this study, the occurrence and distribution of $D$. cephalotes was studied in various water- 


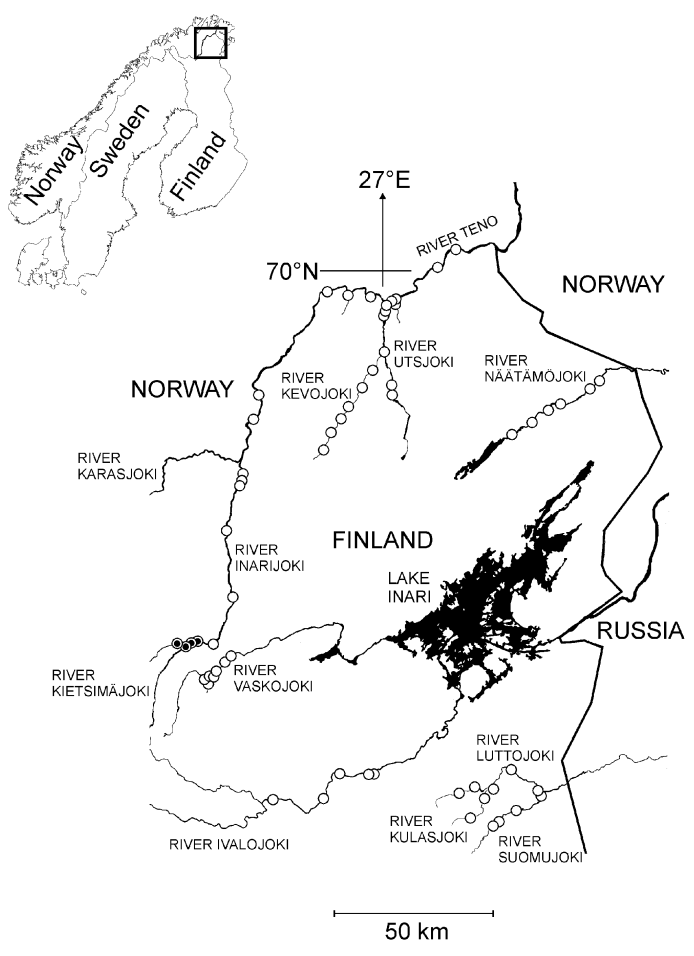

Fig. 1. The study area and benthos sampling sites in northern Finnish Lapland. Presence of Dinocras cephalotes is indicated by filled circles.

sheds in the northernmost Finland. In addition, the age structure of the nymph population was examined.

\section{Material and methods}

A widespread zoobenthos survey was carried out in the northernmost Finnish Lapland (Fig. 1) by the Finnish Game and Fisheries Research Institute, River Tenojoki Fisheries Research Station, in 1990-1991. The purpose of the survey was to monitor possible signs of acidification in riverine benthic macroinvertebrates in the main watersheds of the area (Erkinaro $e t$ al. 2001). A Surber sampler with a mesh of $500 \mu \mathrm{m}$ was used for collecting the benthic animals. Three subsamples, $0.09 \mathrm{~m}^{2}$ each, were collected at each sampling site. Samples were preserved in $80 \%$ ethanol and later sorted in the laboratory on a white plate with the aid of a magnifying lens. In addition to the benthos survey, even more sampling sites in the same watercourses were electrofished in connection with the acidification project and with other fish sampling programmes of the Institute (e.g. Erkinaro et al. 2001).

Given the enormous size and stout appearance of Dinocras cephalotes relative to the other plecopteran nymphs in the study area, and prominent external characteristics of the species, e.g. the large white gill brushes (e.g. Lillehammer 1988), a valid identification of the species was not questioned. Pronotum widths of the specimens were measured to the nearest $0.05 \mathrm{~mm}$ using a binocular microscope with a measuring ocular. Sex-determination was done for large nymphal instars as described in Lillehammer (1988).

\section{Results}

The first Dinocras cephalotes nymphs were captured at the confluence of the River Inarijoki and its largest tributary, River Kietsimäjoki (Fig. 1), in the Suukoski rapid $\left(68^{\circ} 52^{\prime} \mathrm{N}, 25^{\circ} 25^{\prime} \mathrm{E}\right)$, where three large specimens were caught by electrofishing on 22 August 1990. Immediate benthos sampling just above the electrofishing area with Surber sampler resulted in 18 specimens being caught. Sampling by both methods in 1990 and August 1991 resulted in 71 specimens in the Suukoski area and in three consecutive sampling sites downstream the River Inarijoki. No $D$. cephalotes nymphs were found in any other watercourses in the study area (Fig. 1).

The frequency distribution of pronotum widths (PW) indicated four distinct nymphal age groups (Fig. 2). Sexual size dimorphism was especially pronounced in the last, fourth age-group $(3+)$, where females had PW:s exceeding $6 \mathrm{~mm}$, whereas those of males varied between 4.5 and $5.2 \mathrm{~mm}$. In 1991, two specimens ( $\mathrm{PW}=3.7$ and 2.5) were clearly determined as females, and one specimen with an intermediate size $(\mathrm{PW}=2.9)$ was a male. Thus, a distinction between the age groups $1+$ and $2+$ could be made. In 1990 no nymphs belonging to the $2+$ group were caught, but size dimorphism was already detectable among the $1+$ individuals. The young-of-the-year nymphs $(0+)$ were the most abundant cohort in the benthos samples and were clearly detectable from the frequency distribution in both years (Fig. 2).

\section{Discussion}

The distribution of Dinocras cephalotes in northern Finland seems to be restricted to a small geographical area in the River Inarijoki watercourse 
(Fig. 1). Similarly, Huru (1987) describes the Norwegian distribution of the species as patchy and consisting of isolated populations. The closest occurrences of the species in Norway are situated in the River Alta system (Huru 1987), some $100 \mathrm{~km}$ northwest from the Suukoski area. In the present study, no benthos samples were collected further upstream in the River Kietsimäjoki, but electrofishing sampling carried out there might have uncovered the possible occurrence of the species. However, the River Kietsimäjoki remains one of the probable areas for extending the presently known distribution.

Electrofishing seemed to be an effective method for collecting $D$. cephalotes nymphs, especially the larger instars, although most of the specimens were sampled with a Surber benthos sampler. Extensive electrofishing surveys have been carried out in most of the main river systems in the Tenojoki, Näätämöjoki, Paatsjoki (R. Vaskojoki and Ivalojoki) and Tuulomajoki (R. Luttojoki, Kulasjoki, Suomujoki) watercourses (Fig. 1) over several years (e.g. Erkinaro et al. 2001). Thus, the present knowledge of the distribution of the $D$. cephalotes may be reliable, and finding large uncovered distribution areas in these watercourses is unlikely.

Dinocras cephalotes is the only plecopteran species in Fennoscandia with a life cycle of more than two years (Lillehammer 1988). Huru (1987) proposed a life cycle with four or five nymphal years in the northernmost Norway. However, it appears that sexual dimorphism has not been taken into account, and the two oldest age-classes in the figures 3 and 4 in Huru (1987) match well with the different-sized sexes in the $3+$ group in the present study (Fig. 2). Sex-determination of $D$. cephalotes nymphs is easy for the two last agegroups (cf. Lillehammer 1988) but becomes more complicated in $1+$ nymphs, where only the largest specimens could be sexed (Fig. 2), and it is virtually impossible for the youngest nymphs.

Zwick (1996a) documented the ability of $D$. cephalotes eggs to interrupt and resume egg development repeatedly, at a variety of developmental stages, without marked reduction in overall hatching success. This flexibility in the egg development enables prolongation of the embryogenesis over one year if the thermal demand (ca. 600 day degrees above $4{ }^{\circ} \mathrm{C}$; Zwick 1996b) is not
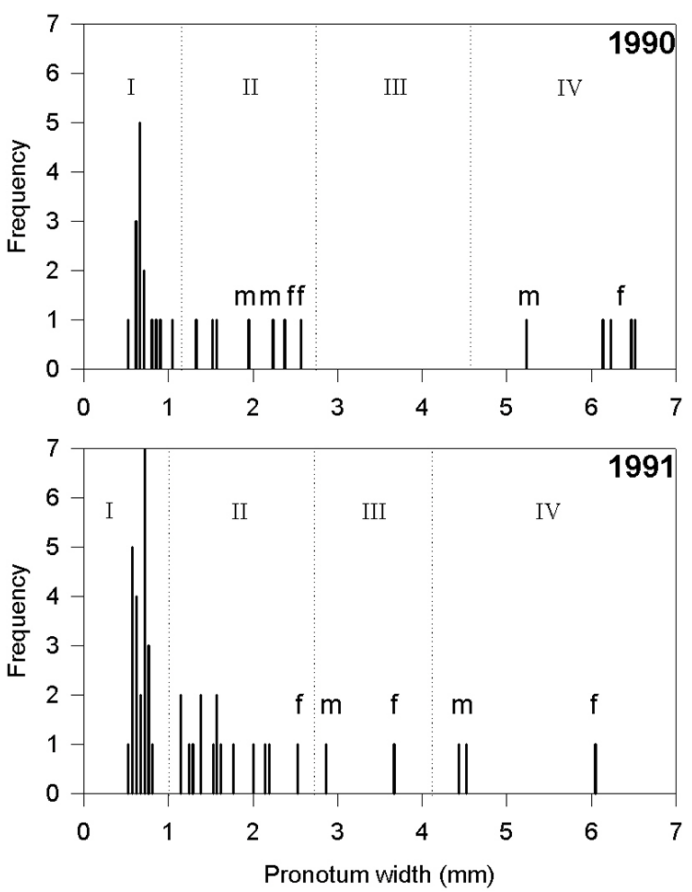

Fig. 2. Frequency distribution of the pronotum widths of Dinocras cephalotes. Suggested age-classes have been indicated with dotted line boundaries and marked with Roman numerals. Sex-determined individuals have been marked with corresponding symbols $(\mathrm{m}=$ male, $\mathrm{f}=$ female $)$.

met in one season. This ability combined with the longevity of $D$. cephalotes nymphs make the lifecycle patterns even more variable. The required thermal threshold is normally reached in one summer in the River Teno system (see temperature data in Erkinaro \& Niemelä [1995] and Erkinaro et al. [1998]). D. cephalotes thus appears to have a total life-cycle of five years with four nymphal years in the northernmost Finland.

Malmqvist and Sjöström (1984) found that microdistribution of D. cephalotes correlated positively with high densities of prey (mainly chironomid larvae) and the presence of moss. In accordance with these findings, the richly mosscovered Suukoski area had by far the highest benthos densities (9600-13 400 individuals $/ \mathrm{m}^{2}$ ) in the entire data set consisting of 90 samples in different river systems in the northernmost Finland (Erkinaro et al. 2001). Moreover, chironomid larvae dominated the benthos community of the Suukoski area. The productivity of the Suukoski 
area presumably results from the abundant lacustrine areas of the River Kietsimäjoki, extending tens of kilometres upstream from the Suukoski. This coincides with the data of Huru (1987), where all the $D$. cephalotes specimens in northern Norway have been found no more than $7 \mathrm{~km}$ from the nearest upstream lake. In addition, lakes may function as warm water storages and thus facilitate meeting the temperature demand for the egg development of $D$. cephalotes in fluvial stretches further downstream.

This record of Dinocras cephalotes increases the number of published records of plecopteran species found in Finland to 36 (Meinander 1980, Kuusela 1996), although Kuusela's (1996) recent list of stonefly species in Finland has already referred to the present record as unpublished information.

Acknowledgements. We thank Eero Niemelä for support during this study, Mikko Erkinaro for help in the field, Matti Kylmäaho for providing the map in Fig. 1, and Dr. Kalevi Kuusela for valuable comments on an earlier draft of the manuscript.

\section{References}

Brinck, P. 1949: Studies on Swedish stoneflies (Plecoptera). - Opuscula Entomol. Suppl. 11: 1-250.

Erkinaro, H., Erkinaro, J., Rask, M. \& Niemelä, E. 2001: Status of zoobenthos and fish populations in subarctic rivers of the northernmost Finland: possible effects of acid emissions from Russian Kola Peninsula. - Water, Air and Soil Pollution 130: 831-836.

Erkinaro, J. \& Niemelä, E. 1995: Growth differences between the Atlantic salmon parr, Salmo salar, of nursery brooks and natal rivers in the River Teno watercourse in northern Finland. - Env. Biol. Fish. 42: 277-287.

Erkinaro, J., Niemelä, E., Saari, A., Shustov, J. \& Jørgensen, L. 1998: Timing of habitat shift by Atlantic salmon parr from fluvial to lacustrine habitat: analysis of age distribution, growth, and scale characteristics. - Can. J. Fish. Aquatic Sci. 55: 2266-2273.
Frutiger, A. 1987: Investigations on the life-history of the stonefly Dinocras cephalotes Curt. (Plecoptera: Perlidae). - Aquat. Insects 9: 51-63.

Huru, H. 1987: Occurrence and life cycle of Dinocras cephalotes ((Curtis), 1827) (Plec. Perlidae) in North Norway. - Fauna Norv. Ser. B 34: 14-18.

Hynes, H. B. N. 1977: A key to the adults and nymphs of British stoneflies (Plecoptera). — Freshw. Biol. Ass. Sci. 17: 1-92.

Kuusela, K. 1996: Updated list of provincial distribution of stoneflies in Finland (Plecoptera). — Sahlbergia 3: 7680 .

Lillehammer, A. 1974: Norwegian stoneflies. II. Distribution and relationship to the environment. — Norsk Ent. Tidskr. 21:195-250.

Lillehammer, A. 1987: Diapause and quiescence in eggs of Systellognatha stonefly species (Plecoptera) occurring in alpine areas of Norway. — Ann. Limnol. 23: 179184.

Lillehammer, A. 1988: Stoneflies (Plecoptera) of Fennoscandia and Denmark. - Fauna Ent. Scand. 21. 165 pp.

Lucy, F., Costello, M. J. \& Giller, P. S. 1990: Diet of Dinocras cephalotes and Perla bipunctata (Plecoptera, Perlidae) in a South-West Irish stream. - Aquat. Insects 12: 199-207.

Malmqvist, B. \& Sjöström, P. 1980: Prey size and feeding patterns in Dinocras cephalotes (Plecoptera). — Oikos 35: 311-316.

Malmqvist, B. \& Sjöström, P. 1984: The microdistribution of some lotic insect predators in relation to their prey and to abiotic factors. - Freshw. Biol. 14: 649-656.

Meinander, M. 1980: Suomen koskikorennot — Finlands bäcksländor (Plecoptera). — Notul. Ent. 60: 7-10.

Mendl, H. \& Müller, K. 1974: Die Plecopteren des Messauregebietes. — Ent. Tidskr. 95: 129-147.

Sjöström, P. 1985: Territoriality in nymphs of Dinocras cephalotes (Plecoptera). - Oikos 45: 353-357.

Ulfstrand, S. 1968: Life cycles of benthic insects in Lapland streams (Ephemeroptera, Plecoptera, Trichoptera, Diptera Simuliidae). - Oikos 19: 167-190.

Zwick, P. 1996a: Capacity of discontinuous egg development and its importance for the geographic distribution of the warm water stenotherm, Dinocras cephalotes (Insecta: Plecoptera: Perlidae). - Annals Limnol. 32: 147-160.

Zwick, P. 1996b: Variable egg development of Dinocras spp. (Plecoptera, Perlidae) and the stonefly seed bank theory. - Freshw. Biol. 35: 81-100. 